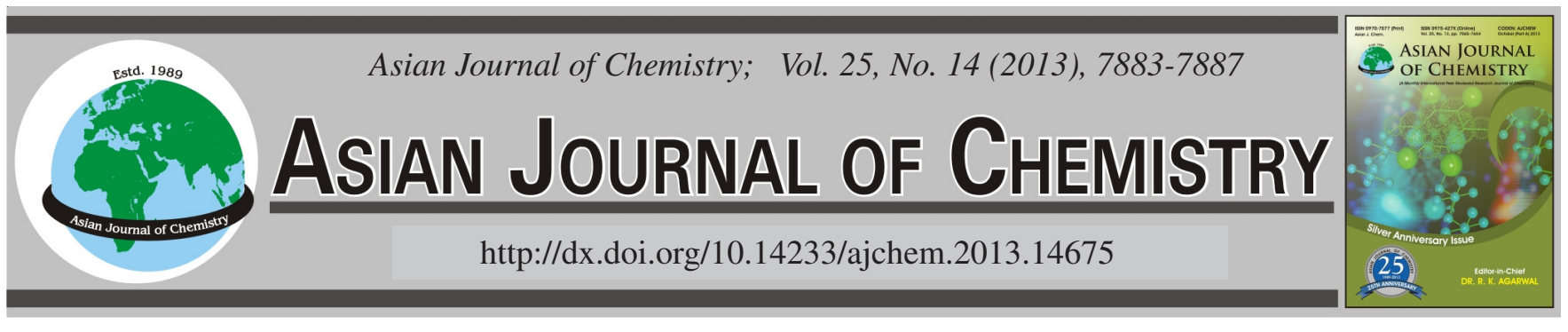

\title{
Heavy Metals in Surface Water in Eastern, Central and Western Tianshan Mountains, Central Asia
}

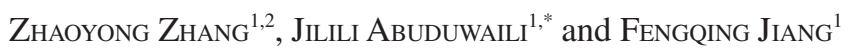

${ }^{1}$ State Key Laboratory of Desert and Oasis Ecology, Xinjiang Institute of Ecology and Geography, Chinese Academy of Sciences, Urumqi 830011, P.R. China

${ }^{2}$ University of Chinese Academy of Sciences, Beijing 100049, P.R. China

*Corresponding author: E-mail: jilil@ms.xjb.ac.cn

(Received: 12 October 2012;

Accepted: 22 July 2013)

AJC-13833

\begin{abstract}
In recent years, the economic development has played an important role in the environment change and now China is one of the fastestgrowing economy countries in the world. With the economic development of Tianshan regions, we wish to know the situation of the heavy metals in water environment of Tianshan Mountains. We used anomaly analysis, correlation analysis, principal component analysis and cluster analysis to analyze the relationship and the occurrence characteristics of heavy metals in the water environment of Tianshan mountains. Results showed that the mean and the standard deviation of heavy metals $\mathrm{Co}, \mathrm{Cr}$, As, Ni present in the western water environment are higher than that in the eastern and central of the Tianshan mountains; meanwhile the mean and the standard deviation of the heavy metals $\mathrm{Cd}, \mathrm{Zn}, \mathrm{Pb}, \mathrm{Hg}, \mathrm{Mn}$ present in the eastern water environment are higher than that of the western Tianshan mountains. The analysis showed the order of heavy metals in the same sample is: $\mathrm{Ni}>\mathrm{As}>\mathrm{Cu}>\mathrm{Zn}>\mathrm{Cr}>\mathrm{Co}>\mathrm{Mn}>\mathrm{Hg}>\mathrm{Cd}>\mathrm{Pb}$. The correlation analysis shows a closer correlation between heavy metals e.g., $\mathrm{Cu}, \mathrm{Mn}, \mathrm{Hg}, \mathrm{Zn}, \mathrm{Ni} ; \mathrm{Mn}, \mathrm{Co}, \mathrm{Ni}$, As. The principal component analysis shows heavy metals of the surface water environment can be divided into the first principal components $(\mathrm{Cu}, \mathrm{Ni}, \mathrm{Co}, \mathrm{As}$ and $\mathrm{Cr}$ ); the second principal components $(\mathrm{Hg}, \mathrm{Zn}, \mathrm{Pb})$ and the third principal components $(\mathrm{Mn}$ and $\mathrm{Cd})$. The analysis grouped ten kinds of heavy metals into three clusters: cluster one $(\mathrm{Co}, \mathrm{Ni}$ and $\mathrm{Cr})$, cluster two $(\mathrm{Cd}, \mathrm{Cu})$, cluster three $(\mathrm{Pb}, \mathrm{Zn}, \mathrm{Mn}$ and $\mathrm{Hg})$. From the analysis the sources of the heavy metals in Tianshan mountains was summed up and distinguish coming from the natural sources and the anthropogenic sources. The research also indicated the rapid economic development in the region have made a negative influence on the environment referred heavy metals situation in Tianshan mountains.
\end{abstract}

Key Words: Surface water, Heavy metals, Source appointment, Tianshan mountains, Central Asia.

\section{INTRODUCTION}

Heavy metals have long been recognized as one of the potentially harmful pollutants to human being's health ${ }^{1,2}$. In recent decades, the research of heavy metals in natural waters environment has become one of the hot areas in environmental research. Heavy metals in the water environment have a variety of sources, including natural and anthropogenic sources ${ }^{3}$. Heavy metals from the natural sources, including weathering of rocks, water erosion and atmospheric deposition, constitute the environmental background values of heavy metals in the water environment. Anthropogenic heavy metal sources discharge most of the pollutants into water bodies ${ }^{4,5}$. It was reported that many heavy metal elements are useful and necessary to lives, however, when bioaccumulation amounts of these heavy metal exceed certain thresholds, significant harmful effects will be taken place on the biological activities of lives ${ }^{6,7}$. Many heavy metals within the magnitude order of equivalent value of ppb play a catalytic role, but when to ppm magnitude order they can often play a harmful role. Previous researches revealed that in many heavy metals (i.e., $\mathrm{Hg}, \mathrm{Cd}$, $\mathrm{Pb}, \mathrm{Cr}, \mathrm{Zn}, \mathrm{Cu}, \mathrm{Co}$, etc.) polluted water bodies, $\mathrm{Hg}$ is the most toxicity, $\mathrm{Cd}$ is the second and $\mathrm{Cr}, \mathrm{Zn}, \mathrm{Cu}$ also have a considerable toxicity. Distribution characteristics of heavy metals cannot only reflect its pollution, but also to some extent, reflect the heavy metals' sources ${ }^{8,9}$.

Recently, Zhang et al. ${ }^{10}$ investigated the heavy metal pollutants of the river flood and found that the water pollution problem during the flooding is more serious and should be paid more attention. Sun ${ }^{11}$ investigated heavy metal pollution in Qing ge da lakes, Xinjiang and found that the lacustrine suspended matter has a stronger adsorption for heavy metals. $\mathrm{Fu}$ and $\mathrm{Liu}^{12}$ use single-factor pollution index evaluated the water quality in the upper and the middle reaches of the Manas river and detected the heavy metals pollutions in the middle of the river. Li et al. ${ }^{2}$ analyzed the sources and the occurrences 
characteristics of heavy metal contents in the Kunas river, Xinjiang and found that the main heavy metals of the river water were: $\mathrm{Cr}, \mathrm{Zn}, \mathrm{Cu}$ and $\mathrm{Cd}$. In addition to this researches also proved with the unreasonable human activities, the heavy metal contents of $\mathrm{As}, \mathrm{Cu}, \mathrm{Cr}$, $\mathrm{Ni}$ in reservoir was higher than that of the irrigation channel ${ }^{13}$.

The previous studies have revealed that the heavy metal contamination in the Tianshan mountains is lower other regions of the world. However, in recent years, the economic "Development of the Western" and "Counterpart support" initiated by China government makes this region have achieved rapid progress, which is beneficial for the society ${ }^{3,14-18}$. In the mean time, the industries and the irregular agriculture production along with the economic development also have a negative influence on the natural environment of the Tianshan mountains by emission the pollutions that containing heavy metals were discharged into the natural environment (including irrigation, motor-pumped wells, creeks and rivers) and the soil environment (cropland, grassland, woodland and bare land). This survey about soil and water environment in Tianshan mountains is considered to be necessary for the environment and humans under background of economic developing along with increasing human activities. This article was focus on the following aspects: (i) How about the occurrence characters of the heavy metals in water environment in Tianshan mountains? (ii) What are the sources of these heavy metals in Tianshan mountains and whether economy developments have made significant impact on the heavy metals concentration in Tianshan mountains?

Based on this survey which covers the whole Tianshan mountains both in water environment and soil environment, the heavy metals' occurrences characters and the sources been studied. Then according to the results we can propose a scientific recommendation for economic development and environmental protection of Tianshan mountains.

Regional environments: Tianshan mountains is a huge mountain located in central Asia, with a mean altitude of 4000 $\mathrm{m}$, length of $2500 \mathrm{~km}$ from the west to the east and mean width of 250-300 km from the north to the south ${ }^{19}$. Tianshan mountains in China, being commonly called as the East Tianshan mountains, stretch in the middle of the Xinjiang Autonomous region of China (Xinjiang hereafter) and divide the Xinjiang into two distinctive natural sub-regions, i.e., the south and the north Xinjiang. Many rivers, lakes and creeks derived from the mountains lied in it. Rich flora and fauna resources as valuable asset are very sensitive to changes in environmental factors (such as heavy metal content) grew up in the mountains and foothills. Large tracts of farmland irrigated by the water from mountains (rivers, creeks) and groundwater (motor-pumped well) by located in foothills. During agricultural production activities unreasonable use herbicides containing heavy metals, fertilizer containing phosphorus, potassium element excessively, inevitably changes have happened on the physical and chemical properties of the soil and water environment by field penetration and the rain wash entered into irrigation channels and groundwater, influencing crop and biological growth and human health.

\section{EXPERIMENTAL}

Samples collection: During August, 2011, 51 samples of surface waters including rivers, irrigation channels, pump wells, creeks and lakes. The samples location, sampling dates, water temperature, vegetation type, samples colour, the latitude and longitude of the sampling site. In laboratory, we chosen 10 kinds of heavy metal elements ( $\mathrm{Pb}, \mathrm{Ni}, \mathrm{Cd}, \mathrm{Co}, \mathrm{Hg}, \mathrm{As}$, $\mathrm{Cu}, \mathrm{Mn}, \mathrm{Zn}, \mathrm{Cr})$ to test ${ }^{15,20}$.

Each water sample was taken $5 \mathrm{~mL}$ to test. All the measurements were made with an Inductively Coupled Atomic Emission Spectrometer model 6500, equipped with a CID86 chip detector. The system is equipped with an integrated unit for hybrid generation. This instrument operates sequentially with both radial and axial torch configurations. The entire system is controlled by Iteva software. Instrument operating conditions for the determination of heavy metals in samples and selected emission lines are shown in Tables 1 and 2, respectively.

TABLE-1

INSTRUMENT OPERATING CONDITIONS FOR DETERMINATION OF HEAVY METALS IN SAMPLES

\begin{tabular}{lc}
\multicolumn{1}{c}{ Spectrometer } & ICAP 6500 \\
\hline Nebulizer & Concentric \\
Spray chamber & Cyclonic \\
Radio frequency power $(\mathrm{W})$ & 1150 \\
Principal argon flow rate $(\mathrm{L} / \mathrm{min})$ & 12 \\
Auxiliary argon flow rate $(\mathrm{L} / \mathrm{min})$ & 0.5 \\
Nebulizer flow rate $(\mathrm{L} / \mathrm{min})$ & 0.5 \\
Sample flow rate $(\mathrm{mL} / \mathrm{min})$ & 1.0 \\
Detector & CID86 \\
\hline
\end{tabular}

\begin{tabular}{cccc}
\multicolumn{4}{c}{ TABLE-2 } \\
& \multicolumn{4}{c}{ SELECTED EMISSION LINES } \\
\hline Element & $\lambda(\mathrm{nm})$ & Element & $\lambda(\mathrm{nm})$ \\
\hline $\mathrm{As}$ & 193.7 & $\mathrm{Mn}$ & 257.8 \\
$\mathrm{Cd}$ & 228.8 & $\mathrm{Ni}$ & 231.6 \\
$\mathrm{Co}$ & 228.6 & $\mathrm{~Pb}$ & 220.3 \\
$\mathrm{Cr}$ & 283.5 & $\mathrm{Zn}$ & 213.8 \\
$\mathrm{Cu}$ & 324.7 & $\mathrm{Hg}$ & 253.6 \\
\hline
\end{tabular}

Statistical methods: Typical statistical analysis, Correlation analysis, Principal component analysis and Cluster analysis were used in the data process in this article to analyze the occurrence characters of the heavy metals: $\mathrm{Mn}, \mathrm{Zn}, \mathrm{Cr}$, $\mathrm{Cd}, \mathrm{Hg}, \mathrm{Cu}, \mathrm{Ni}, \mathrm{Co}, \mathrm{As}, \mathrm{Pb}$, all the data during progress handled by these methods were carried out by software spss 20.0 .

\section{RESULTS AND DISCUSSION}

Statistical analysis: Typical analysis was referred to analyze the variable as the ranges, the mean and the std. deviation, characteristics for intuitive understanding can be obtained by the method (Table-3).

The statistic characters of heavy metals (Table-3) in the water environment of Tianshan mountains reveals the heavy metals: $\mathrm{Mn}, \mathrm{Cu}, \mathrm{Zn}, \mathrm{Cr}, \mathrm{Pb}, \mathrm{Ni}, \mathrm{Cd}, \mathrm{Co}, \mathrm{Hg}$ and $\mathrm{As}$ range (Table-4): 1.697-11.414, 1.61-12.568, 0.009-0.227, 25.35691.876, 0.059-0.282, 0.699-2.546, 0.111-0.559, 4.994-22.672 and $1.697-11.414 \mu \mathrm{g} / \mathrm{L}$. The analysis showed the order of the heavy metals concentration in the Tianshan mountains are: the central $>$ the eastern $>$ the western Tianshan mountains.in 


\begin{tabular}{|c|c|c|c|c|c|c|c|c|c|c|}
\hline \multicolumn{11}{|c|}{$\begin{array}{c}\text { TABLE-3 } \\
\text { DESCRIPTIVE STATISTICS OF HEAVY METALS IN TIANSHAN MOUNTAINS }\left(\mu \mathrm{g} \mathrm{L}^{-1}\right)\end{array}$} \\
\hline Eastern & $\mathrm{Mn}$ & $\mathrm{Cu}$ & $\mathrm{Zn}$ & $\mathrm{Cr}$ & $\mathrm{Pb}$ & $\mathrm{Ni}$ & $\mathrm{Cd}$ & Co & $\mathrm{Hg}$ & As \\
\hline Min & 0.063 & 0.271 & 0.085 & 0.504 & ND & 5.375 & ND & 0.159 & ND & 0.705 \\
\hline $\operatorname{Max}$ & 1.332 & 11.414 & 4.903 & 4.342 & 0.029 & 91.876 & 0.282 & 2.546 & 0.381 & 14.674 \\
\hline Mean & 0.319 & 2.276 & 1.262 & 1.180 & 0.005 & 26.864 & 0.067 & 0.732 & 0.113 & 5.33 \\
\hline Coefficient of variation & 1.087 & 1.33 & 1.022 & 0.701 & 1.530 & 0.66 & 1.065 & 0.67 & 1.787 & 0.818 \\
\hline \multicolumn{11}{|c|}{ Central } \\
\hline Min & 0.036 & 0.364 & 0.185 & 0.463 & ND & 7.383 & ND & 0.201 & ND & 1.017 \\
\hline Max & 1.91 & 2.985 & 12.568 & 3.462 & 0.227 & 46.738 & 0.171 & 1.181 & 0.559 & 22.672 \\
\hline Mean & 0.509 & 1.257 & 2.511 & 1.125 & 0.025 & 21.66 & 0.055 & 0.595 & 0.137 & 5.562 \\
\hline Coefficient of variation & 1.121 & 14.654 & 1.292 & 0.844 & 2.527 & 0.601 & 0.928 & 0.575 & 1.072 & 1.029 \\
\hline \multicolumn{11}{|c|}{ Western } \\
\hline Min & 0.09 & 0.404 & ND & 0.358 & ND & 9.022 & 0.011 & 0.222 & ND & 1.31 \\
\hline Max & 1.317 & 8.469 & 5.397 & 4.598 & 0.005 & 54.069 & 0.128 & 1.391 & 0.33 & 13.78 \\
\hline Mean & 0.253 & 1.188 & 1.363 & 1.602 & 0.002 & 26.858 & 0.049 & 0.739 & 0.085 & 4.27 \\
\hline Coefficient of variation & 1.197 & 1.704 & 0.921 & 0.786 & 1.198 & 0.458 & 1.731 & 0.454 & 0.991 & 0.823 \\
\hline \multicolumn{11}{|c|}{ Total } \\
\hline Min & 1.697 & 1.610 & 1.290 & 0.009 & 25.536 & 0.059 & 0.699 & 0.111 & 4.994 & 1.697 \\
\hline $\operatorname{Max}$ & 11.414 & 12.568 & 4.598 & 0.227 & 91.876 & 0.282 & 2.546 & 0.559 & 22.672 & 11.414 \\
\hline Mean & 1.398 & 1.24 & 0.777 & 3.563 & 0.589 & 0.98 & 0.588 & 0.947 & 0.922 & 1.398 \\
\hline Coefficient of variation & 11.414 & 12.568 & 4.598 & 0.227 & 91.876 & 0.282 & 2.546 & 0.559 & 22.672 & 11.414 \\
\hline
\end{tabular}

the mean time the total concentration of heavy metals are: $\mathrm{Ni}$ $>\mathrm{As}>\mathrm{Cu}>\mathrm{Zn}>\mathrm{Cr}>\mathrm{Co}>\mathrm{Mn}>\mathrm{Hg}>\mathrm{Cd}>\mathrm{Pb}$. Table-4 also revealed that the mean and the coefficient of variation of the heavy metals $\mathrm{Mn}, \mathrm{Cu}, \mathrm{Zn}, \mathrm{Pb}, \mathrm{Cd}, \mathrm{Hg}$ of the eastern Tianshan mountain are much larger than the central and western Tianshan mountains; meanwhile the mean and the coefficient of variation of the heavy metals $\mathrm{Co}, \mathrm{Ni}, \mathrm{Ar}, \mathrm{Cr}$ of the western Tianshan mountain are much larger than the central and eastern Tianshan mountains. The total satistic showed the high mean value of the heavy metal $\mathrm{Mn}, \mathrm{Cu}, \mathrm{Zn}, \mathrm{Pb}, \mathrm{Cd}, \mathrm{Hg}$ all contributed by the heavy metals in the eastern and central of the Tianshan mountains, while the high mean value of the heavy metal Co, $\mathrm{Ni}, \mathrm{Ar}, \mathrm{Cr}$ all contributed by the heavy metals in the western of the Tianshan mountains.

Correlation analysis: The Pearson correlation coefficient can be used directly represent the relationships between variables by correlation coefficient in $p<0.05$ and reveals the strength of the linear relationship. SPSS 20.0 software widely used in statistics in many disciplines, data were used analyzed obey these steps during process in the article: firstly, all the data were converted into values, choosing bivariate correlation analysis and person correlation coefficient, making sided test, at last the correlation matrixes (where the samples of the soil and water was calculated separately) were obtained (Table-4).

The results reveal that between samples many heavy metals have more complex relationships in $p<0.05$, the corre- lation coefficients of $\mathrm{Cu}$ and $\mathrm{Zn}, \mathrm{Pb}$ are $0.324,0.341$ was proved positive. In $p<0.05$, the correlation coefficients of $\mathrm{Mn}, \mathrm{Hg}, \mathrm{Zn}, \mathrm{Pb}$ and $\mathrm{Cd}$ are 0.497, 0.688, 0.557, 0.155 and 0.405 which are also positive. Meanwhile the correlation coefficient of $\mathrm{Ni}$ and As, Co were 0.528, 0.494 and 0.995, in $p<0.05$, it is also proved positive.

Principal component analysis: Principal component analysis was often used to classify the variables by which the main controlling factors can be obtain and the source can be traced by combing the backgrounds of sampling sites [by the soil texture, the colour, the parent materials (humus content), the composition (the gravel contents), the surrounding environment (intensity of human activities and whether pollution sources sited around)].

The result (Fig. 1) carried by the software SPSS 20.0 with all the data changed into values through dimensionality and factor analysis, extracting the non-rotated factor loadings reveals the main components of the heavy metals present in the soil environments: the first is $\mathrm{Cu}, \mathrm{Zn}, \mathrm{Pb}$; the second is $\mathrm{Co}$, $\mathrm{Cr}, \mathrm{As}, \mathrm{Ni}$; the third is $\mathrm{Mn}, \mathrm{Cd}, \mathrm{Hg}$. The cumulative contributions (in the three principal components as 36.852, 64.847 and $77.927 \%$ ) indicate the efficient analysis during the process.

Cluster analysis: The Cluster analysis showed that the data was processed by the below steps in the software SPSS 20.0, first they were change into values then substituted by dimensionality and factor analysis, using average linkage

\begin{tabular}{|c|c|c|c|c|c|c|c|c|c|c|}
\hline \multicolumn{11}{|c|}{$\begin{array}{c}\text { TABLE-4 } \\
\text { CORRELATION MATRIX OF HEAVY METALS }\end{array}$} \\
\hline & $\mathrm{Cu}$ & $\mathrm{Mn}$ & $\mathrm{Hg}$ & $\mathrm{Zn}$ & $\mathrm{Pb}$ & $\mathrm{Ni}$ & $\mathrm{Cr}$ & $\mathrm{Cd}$ & As & Co \\
\hline $\mathrm{Cu}$ & 1.000 & - & - & - & - & - & - & - & - & - \\
\hline $\mathrm{Mn}$ & 0.007 & 1.000 & - & - & - & - & - & - & - & - \\
\hline $\mathrm{Hg}$ & -0.159 & $0.497 * *$ & 1.000 & - & - & - & - & - & - & - \\
\hline $\mathrm{Zn}$ & $0.324 *$ & $0.688^{* *}$ & $0.487 * *$ & 1.000 & - & - & - & - & - & - \\
\hline $\mathrm{Pb}$ & 0.439 & $0.557 * *$ & $0.620 * *$ & $0.712 * *$ & 1.000 & - & - & - & - & - \\
\hline $\mathrm{Ni}$ & $0.558 * *$ & -0.218 & $-0.402 * *$ & 0.109 & -0.123 & 1.000 & - & - & - & - \\
\hline $\mathrm{Cr}$ & $0.041^{*}$ & -0.031 & -0.015 & 0.194 & 0.270 & $0.528^{* *}$ & 1.000 & - & - & - \\
\hline $\mathrm{Cd}$ & $0.668 * *$ & $0.155^{* *}$ & $0.041 * *$ & $0.421 * *$ & 0.228 & $0.092 * *$ & 0.241 & 1.000 & - & - \\
\hline As & $0.518 * *$ & $0.405 * *$ & 0.223 & $0.545^{* *}$ & $0.277 *$ & $0.494 *$ & 0.199 & $0.440 * *$ & 1.000 & - \\
\hline Co & $0.593 * *$ & -0.208 & $-0.402 * *$ & 0.131 & -0.114 & $0.995^{* *}$ & $0.550 * *$ & $0.411^{* *}$ & $0.325^{*}$ & 1.000 \\
\hline
\end{tabular}




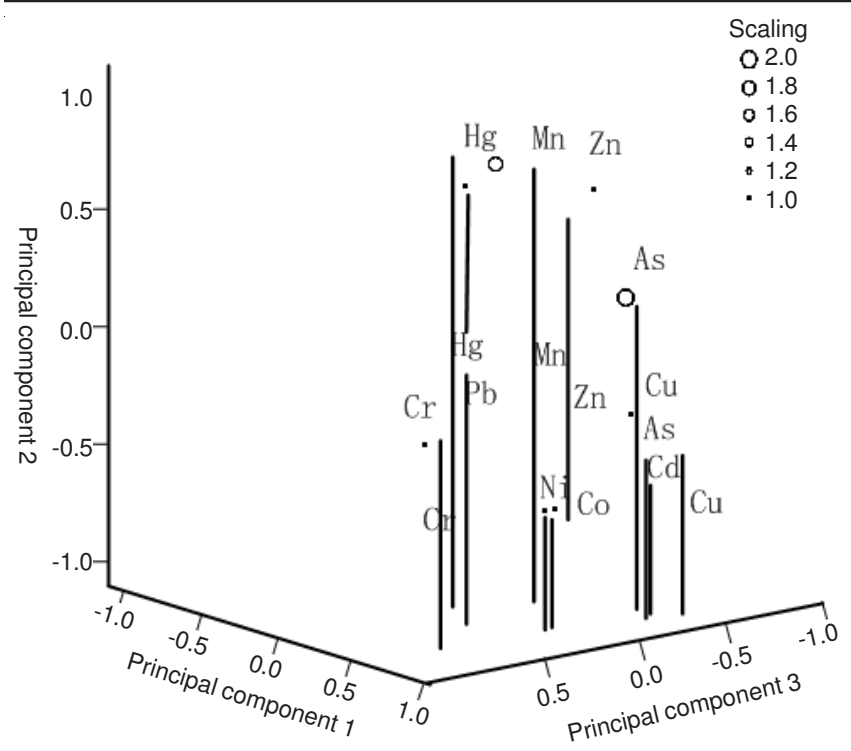

Fig. 1. Principal component factor scatter

(between groups) rescaled distance-2 as the standard. The result showed ten kinds of heavy metals were grouped into three significant clusters (Fig. 2): the first is $\mathrm{Co}, \mathrm{Ni}, \mathrm{Cr}$, As the second is $\mathrm{Cd}, \mathrm{Cu}$, the third is $\mathrm{Pb}, \mathrm{Zn}, \mathrm{Mn}, \mathrm{Hg}$.

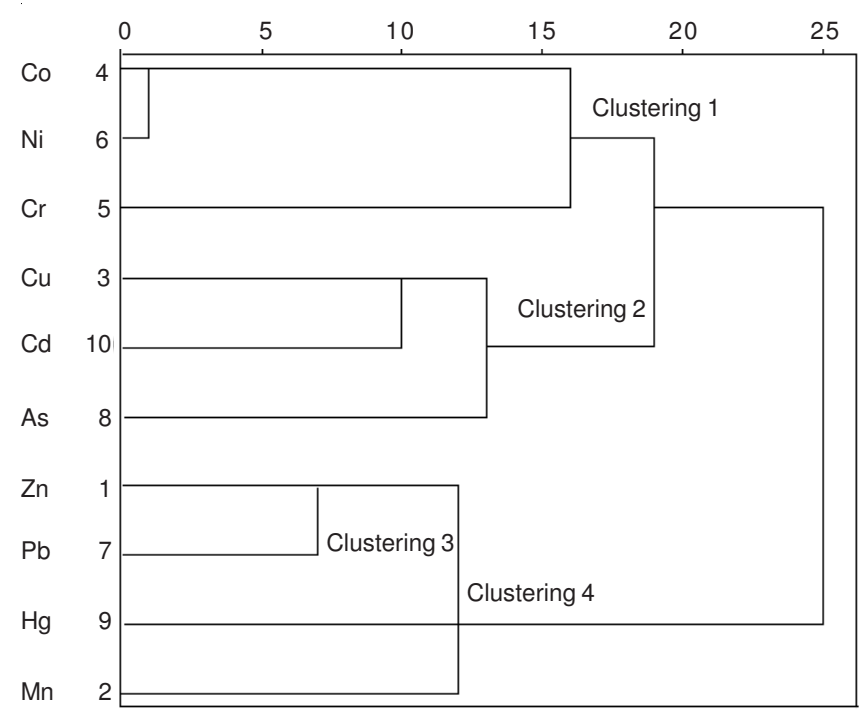

Fig. 2. Heavy metal group cluster analysis tree

Comparing of the heavy metals concentration of the Tianshan mountians: The above analysis showed that the order of the heavy metals contents in Tianshan mountains is: eastern $>$ central $>$ western. Which closely related to the economic development of these regions, in the eastern and central regions of the Tianshan mountains, the economic has a rapid progress and a lot of Industrial enterprises migrated here from the Mainland, which makes the waste emissions containing high concentrations of heavy metals discharged by these enterprises have greatly polluted the environment, e.g., in the Barkol lake, due to the nearby chemical companies, the emission of pollutants has resulted in a serious deterioration of the lake and emit odour, now the bottom of the lake is covered with black sludge which contains large amounts of heavy metals. In the central Tianshan mountains which as the center of the Urumqi city, now is the economic development center of Xinjiang autonomous region and the pollution situation that was caused by numerous enterprises is also serious, such as the Fukang heavy chemical industry park which was located in the east of Urumqi, emission large quantities of wastes into the surrounding environment, in the daytime there are a lot of black smoke into the air and the air was filled with a pungent odor, meanwhile there are a large number of wastewater, slag which were discharged into the surrounding environment, making a negative impact on the environment and human health. The comparison of the eastern and central of Tianshan mountains, the economic development of the west Tianshan mountains which as the central of Ili valley is slower than above regions. On the other hand it makes the environmental influenced less by the humans' activities. During this research it is observed that the samples in this region often with the low concentration of the heavy metal. However, in recent years "Counterpart Yuan Jiang Policy" managed by the China government, serious change (the increase of the intensity of human activities has had an negative impact on the environment than ever before) have happened in these region, such as the samples ZT-05 and ZT-08 which located in the bank of Ili river, the polluting heavy metal concentration also high in some samples, e.g., $\mathrm{Pb}$ and $\mathrm{Hg}$ are $0.05,0.33,0.045$ and $0.31 \mu \mathrm{g} \mathrm{L} \mathrm{L}^{-1}$, which are much higher than that in other samples, though the mean concentration of the heavy metals is much low than the eastern and western of the Tianshan mountains.

Sources of the heavy metals of the Tianshan mountains: The analysis showed the heavy metals were all come from the natural sources and the anthropogenic sources. The water samples with high concentration of heavy metals e.g., Ni, Cr, $\mathrm{Co}, \mathrm{As}, \mathrm{Cu}$, often located in the rivers floodplain and the mountains have much rocks and natural environment are the sources of these heavy metals. Therefore, these elements present in the rocks and the dry floodplain and the bare rocks. However, the polluting heavy metals $\mathrm{Hg}, \mathrm{Pb}, \mathrm{Mn}$ and $\mathrm{Cd}$, all come from the anthropogenic sources (slag discharged by the industries and irregular agriculture production), in the water environment the samples with high concentration of these elements were retrieved from the irrigation channels, the motor-pumped well and the rivers that close to the town, where the water environment can be easily influenced by the pesticides in agriculture production containing heavy metals, in the sample BY-03 the concentration of $\mathrm{Hg}$ reached $0.54 \mu \mathrm{g} \mathrm{L}{ }^{-1}$ which is higher than others, combining the sample background it was retrieved from the irrigate channel, by the investigation made during sampling we determined the farmers often use mercury herbicide containing have metals $\mathrm{Hg}$ and the element was penetrated into the channel by irrigation and rainwater; in the samples ZT-05 and $\mathrm{ZT}-06$ the concentrations of $\mathrm{Pb}$ and $\mathrm{Zn}$ are reached $0.33,12.45$, 1.29 and $10.51 \mu \mathrm{g} \mathrm{L}^{-1}$, which are higher than other samples, by backgrounds we acquired that these samples all taken from the river, with a lead-zinc mine lied on the edge, the slag caused by mining discharged into the river, making the main source.

From the above analysis it is noted that the correlation analysis and cluster analysis are consist with the natural sources and the anthropogenic sources, such as the heavy metals $\mathrm{Cu}$, 


\begin{tabular}{cccccccccccc}
\hline & \multicolumn{10}{c}{ TABLE-5 } \\
\multicolumn{10}{c}{} & \multicolumn{10}{c}{ EUCLIDEAN DISTANCE MAP OF HEAVY METAL VARIABLES } \\
\hline & $\mathrm{Pb}$ & $\mathrm{As}$ & $\mathrm{Cd}$ & $\mathrm{Hg}$ & $\mathrm{Mn}$ & $\mathrm{Cu}$ & $\mathrm{Zn}$ & $\mathrm{Co}$ & $\mathrm{Cr}$ & $\mathrm{Ni}$ \\
\hline $\mathrm{Pb}$ & 0.000 & - & - & - & - & - & - & - & - & - \\
$\mathrm{As}$ & 0.000 & 0.000 & - & - & - & - & - & - & - & - \\
$\mathrm{Cd}$ & 0.000 & 0.000 & 0.000 & - & - & - & - & - & - & - \\
$\mathrm{Hg}$ & 0.728 & 0.000 & 0.000 & 0.000 & - & - & - & - & - & - \\
$\mathrm{Mn}$ & 0.574 & 0.000 & 0.000 & 0.371 & 0.000 & - & - & - & - & - \\
$\mathrm{Cu}$ & 0.062 & 0.121 & 0.689 & 0.840 & 0.807 & 0.000 & - & - & - & - \\
$\mathrm{Zn}$ & 0.890 & 0.170 & 0.415 & 0.326 & 0.244 & 0.427 & 0.000 & - & - & - \\
$\mathrm{Co}$ & 0.974 & 0.442 & 0.406 & 0.824 & 0.855 & 0.410 & 0.598 & 0.000 & - & - \\
$\mathrm{Cr}$ & 0.993 & 0.675 & 0.658 & 0.818 & 0.955 & 0.698 & 0.748 & 0.313 & 0.000 & - \\
$\mathrm{Ni}$ & 1.000 & 0.468 & 0.425 & 0.839 & 0.876 & 0.441 & 0.624 & 0.218 & 0.328 & 0.000 \\
\hline
\end{tabular}

$\mathrm{Zn}$ and $\mathrm{Cr}$ have a strong correlation in $p<0.05$ and they all come from the natural sources, the heavy metals $\mathrm{Mn}, \mathrm{Hg}, \mathrm{Zn}$, $\mathrm{Pb}, \mathrm{Cd}$ have a strong correlation in $p<0.05$ and they all come from anthropogenic sources, meanwhile during the cluster analysis, the heavy metals $\mathrm{Co}, \mathrm{Ni}, \mathrm{Cr}$ and $\mathrm{Cd}, \mathrm{Cu}$ were divided into a separated groups and they come from the natural sources and the heavy metals $\mathrm{Pb}, \mathrm{Zn}, \mathrm{Mn}, \mathrm{Hg}$ were also clustering as a group, these analysis were consistent with the correlation analysis. Based on the analysis, it is obvious that the heavy metals $\mathrm{Cu}, \mathrm{Ni}, \mathrm{Cr}, \mathrm{Co}$, As come from the natural sources and with a strong correction between them, at the same time, the heavy metals $\mathrm{Hg}, \mathrm{Zn}, \mathrm{Pb}, \mathrm{Mn}$ and $\mathrm{Cd}$ all come from the anthropogenic sources caused by unreasonable humans' activities.

Combining the samples of the high contents of $\mathrm{Co}, \mathrm{Ni}$, $\mathrm{Cr}$, e.g., the $\mathrm{XN}-01$ and $\mathrm{XN}-01$ which located in the dry valley where have little humans activities inflation and the high concentration of these element all come from the bare rocks by the natural weathering and the water erosion of upstream, consequently, these elements can gather in these samples places; while the high concentrations of the heavy metals the samples $\mathrm{Cd}, \mathrm{Cu}$, such as FM-01 and FM-02 which all located in the Heavy Chemical Industry Park of Fukang city, Xinjiang Autonomous Region, China. The analysis showed the these heavy metals comes from the wastes discharged from the industries. In the mean time the samples ZT-06, ZT-07 and $\mathrm{XN}-05$ which have the high concentration of $\mathrm{Pb}, \mathrm{Zn}, \mathrm{Mn}, \mathrm{Hg}$ all located near the lead and zinc mine and near the samples there has a parking lot, the heavy metals $\mathrm{Pb}$ and $\mathrm{Zn}$ may be come from the mineral extraction and the car exhaust ${ }^{1}$.

\section{Conclusion}

From the above analysis it is noted that the heavy metals status of the Tianshan mountains are good. The heavy metals concentration of the water environment in Tianshan mountains are also lower than other regions of the word, while recent years economic development has made a negative influence on the environment, the emissions of pollutants by the irrational human activities has become the main source of the high content of heavy metals of $\mathrm{Mn}, \mathrm{Hg}, \mathrm{Zn}$ and $\mathrm{Pb}$.

The analysis implies that with the rapid economic development, the heavy metal concentrations changed abnormally in some regions, more obvious in the eastern and central
Tianshan mountains and the excessive emission of the heavy metals have occurred negative influenced on the plants growth and the humans health. The environment of Tianshan mountains is very fragile and once contamination is difficult to recover, The soil and water environment of Tianshan mountains is very fragile, once contamination is difficult to recover, to maintain a healthy environment we should take measures. For heavier polluted regions near the industrial park and other areas with heavier heavy metal pollutions, measures such as soil leaching and phytoremediation should be carried to mitigate the degree of contamination.

\section{ACKNOWLEDGEMENTS}

This study was supported by the Knowledge Innovation Program of the Chinese Academy of Sciences (KZCX2-YWGJ04; KZCX2-EW-308).

\section{REFERENCES}

1. N.N. Komarova and E.M. Sul'man, Russian J. Appl. Chem., 75, 509 (2002).

2. M.Y. Li, J.R. Xu and Z.W. Shi, Environ. Chem., 28, 716 (2009).

3. M. Barakat and E. Schmidt, Desalination, 256, 90 (2010).

4. M. Egli, G. Sartori and A. Mirabella, Sci. Total Environ., 408, 931 (2010).

5. C. Mendiguchía, C. Moreno and M. García-Vargas, Chemosphere, 69, 1509 (2007).

6. A. Gaudry, S. Zeroual, L. Gaie, M. Moskura, Z. Boujrhal, R. Cherkaoui, E. Moursli, A. Guessous, A. Mouradi, T. Givernaud and R. Delmas, Water Air Soil Pollut., 178, 267 (2007).

7. L. Li, X.Z. Hu, R.T. Liu, B.H. Zhou and X.C. Jin, China Environ. Sci., 30 (2010).

8. A.A. Gharaibeh, Environ. Monitoring Assessment, 160, 425 (2010).

9. E.U. Onweremadu, Appl. Phys. Eng., 9, 366 (2008).

10. C. Ye, S.Y. Li, Y.L. Zhang, Q.F. Zhang, J. Hazard. Mater., 191, 366 (2011).

11. Z.J. Sun, J. Xinjiang Univ. (Nat. Sci. Ed.), 27, 363 (2010).

12. S.Q. Fu and N.L. Liu, Jilin Water Resources, 4 (2010).

13. J. Du, Y. Fan and X. Qian, Environ. Pollut. Control, 33, 58 (2011).

14. V.B. Stefan, P. Alexandeu and A.S. Daniel, Revista de Chimie, 59, 986 (2008).

15. P.Y. Zhong, X.L. Wen and Q.L. Yu, J. Geochem. Explor., 108, 27 (2011).

16. Y.J. Yi, Z.F. Yang and S.H. Yang, Environ. Pollut., 159, 2575 (2011).

17. M.J. Mahanta and K.G. Bhattacharyya, Environ. Monit. Assess., 173, 221 (2011).

18. C.C. Miao and C.F. You, J. Geochem. Explor., 105, 106 (2010).

19. R.J. Hu, H. Ma, Z.L. Fan, Q. Yang, S.F. Wu and Y.Y. Huang, J. Nat. Resour., 17 (2002).

20. T. Hosono, C.-C. Su, F. Siringan, A. Amano and S.-i. Onodera, Marine Pollut. Bull., 60, 780 (2010). 